\title{
Architectural Representation between Imagination and Revelation
}

\author{
Elena-Codina Duşoiu \\ Department Study of Form and Ambience, Ion Mincu University of Architecture and Urbanism, Bucharest 010014, Romania
}

\begin{abstract}
This paper is born from the intimate belief that solutions for the future are to be found in the past. No transformation is irreversible enough to destroy the experiences of the past, unified as a core in tradition. Those come into light whenever the proper conditions are created. From the point of view of architecture, representation is the basis for the transmission of knowledge, ideas, feelings, etc. The method of the paper is to put in antithesis two concepts which define the present world of representation: real (associated to transcendent revelation) and virtual (understood as result of human imagination). An itinerary through the philosophy of Plato and Plotin, ancient Greek, Byzantine, Gothic architecture, etc., is proposed, until encountering the moment of the death of revelation and the birth of the arbitrary, which is connected to the supremacy of the image. This journey through aesthetic conceptions brought major changes in art and society during the centuries. Recuperation of the involvement of all human senses into perception of space and understanding of the built environment of life as revelation, and not as a simple interface of images, may lead now to a revolution of urban spirit, based on a relationship with the city inspired from the values promoted by Socrates and later developed into Christianity, that proved their permanence across the millenniums.
\end{abstract}

Key words: Representation, imagination, real, virtual, revelation, communication.

\section{Introduction}

Inspired by personal observations in search of representing the imagined space in the most proper way, the paper comes across an aesthetic historical evolution of the representation and perception of architecture, based on two main directions: the so-called realistic representation, produced for the intellect (or representation as imagination), based on the study of physical and optical laws, and representation through revelation ( $\varepsilon \pi v \phi \alpha v \varepsilon l \alpha)$, consecrated by the Byzantine world, eastern prolongation of the Roman culture. From a historical perspective, coming to modern times, we cannot but reach the "death of revelation" moment, clearly embodied by the modern era. The image, conventional representation of reality, takes the place of reality itself and this fact appears to be mainly due to lack of

Corresponding author: Elena-Codina Duşoiu, associate professor, research fields: visual arts, rehabilitation of buildings, sustainable and vernacular architecture. E-mail: codina99@yahoo.com. revelation.

Bringing back the soul into architectural perception (and artistic perception, in general) can be reached by involving all senses into this act, and not just the sight. This approach was in fact considered by famous artists such as Constantin Brâncuşi or Marcel Duchamp since the first part of the 20th century [1]. This perspective is now the response to a necessity, asking us to re-act and participate, not just look at and criticize. This attitude, imposed by contemporary times, is here denominated, "the death of the spectatorship era". This sense of active atitude needs to be re-learned by understanding historical aproaches and also by personal involvement into reality, in this case considered as architectural space. This method may have direct connections with a new perspective for architecture education and architecture practice in general, which emerged today, in a worldwide crisis of identity. Restoring the role of a creator for the architect, connecting him to revelation, can save his condition that is now reduced to the one of a "space 
producer". Nevertheless, this perspective may be extended to other fields dialing with artistic creation.

The structure of the paper is based on a survey on the concept of representation, as found in some well-known philosophical works produced by humanity in the last 2000 years, such as: "The Myths" and "The Banquet" of Plato, "Eneadas" by Plotin, "The Critique of Judgment" by Immanuel Kant, "The History of Religious Ideas and Beliefs" by Mircea Eliade, "The Work of Art in the Age of Mechanical Reproduction" by Walter Benjamin, "Architecture and the Crisis of Modern Science" by Alberto Pérez-Gomez. These titles are indicated chronologically and are leading to the conclusion of the constant change from representation as "revelation of reality" to representation that replaces reality. These main references were chosen as nodal points in the chronological survey, as steps ensuring the continuity of the reasoning adopted in this paper.

The Byzantine conception, explaining architecture created through revelation, is presented according to the observations of Robert Ousterhout [2], for the architectural point of view and Christos Yannaras [3], for the theological point of view. The definition of representation, the main key-term of the research, is considered from a psychological, philosophical and artistic point of view.

The inner purpose of the paper is to restore the transcendent value of architectural representation and a deeper understanding of architectural creation, with direct consequences on human life.

\section{Method and Materials}

As mentioned before, the basic bibliography of the paper consists in working with well known concepts from consecrated titles from philosophy and aesthetics, chosen in order to illustrate the evolution of thinking on the theme of architectural representation. The paper dials with two opposite notions: the real (understood in the absolute sense of the word) and the virtual (synonym of imaginary, unreal). The discourse is built on the antithesis of these two terms.

Here are some definitions of key terms used in the paper:

- authentic = real or true; being in fact what it is claimed to be [4];

- authenticity = property of being authentic, contact with the original, awareness of the real. The here and now of the original constitute the concept of its authenticity (...) Authenticity of an object is the sum of everything that can be transmitted in it from the origin-from its material duration until its historical testification [5];

- communicate $=$ to give successfully (thoughts, feelings, ideas or information) to others [4];

- communication $=$ mutual transmission and reception of ideas, feelings, etc., between two subjects (definition of the author);

- imagination $=$ ability to form mental pictures or ideas [4];

- represent $=$ to show or describe something; to be a sign or symbol of something [4];

- representation $=$ the act or the result of representing, by a human subject for himself or for another (definition of the author);

- real = existing in fact, not imaginary [4], true (in the absolute sense of the word). I use the notion of reality both in its phenomenological sense and in the domain of intentionality existing between me incarnated and the exterior world [6];

- virtual $=$ almost, virtual reality $=$ a set of images and sounds produced by a computer which seem to represent a place or a situation [4], imaginary, only existing in the subjects' mind, not real, copy of the copy [7].

Here is a working scheme representing a synthesis of the concepts defining the two antithetic terms used to express the essence of architectural representation: real and virtual. These terms appear to be in a deep contrast: while reality is based on the revelation of authenticity, the virtual world is formed out of the representation of the imaginary. This kind of 
representation is mainly perceived through the sight, while an authentic experience requires the involvement of all senses. Reality means uniqueness, therefore infinite diversity, while the realization of virtual representation requires a common code of rules. And, as an overall conclusion, in a Kantian perspective, reality means the a priori intuition of the truth, while virtual representation is based on an $a$ posteriori portrayal of the perception of reality.

The paper follows this distinction in different phases of the evolution of human thinking, starting with Platonian philosophy from ancient Greek times, continuing with the experience of revelation in art refined by East-Roman (Byzantine) culture and the intelligent architecture of reasoning created during the Gothic period, getting to the point of the death of the transcendent vision in architecture, whose starting point was identified by Alberto Perez-Gomez in the Enlightenment [6] and getting to the moment of the supremacy of image, consecrated by the modern era with its new tools: photography, cinema, etc. The present moment, when virtual representation gained a refinement which was never reached before and the imaginary surpassed the limits of just the sense of the sight, appears as a direct continuator of the "image supremacy" from the modern times. However, the conscience of the end of the spectatorship era developed in the last years, preaching the necessity of an active involvement of the architect in reality and not just a connection with virtual reality.

\section{Two Stories on Communicating Architecture}

\subsection{Communicating Architecture-1st Story}

While being a student in architecture I used to dream about walking inside the houses I was designing, which was much more pleasant and inspiring than the act of drawing itself. I knew a good project was the one that drove me to such an itinerary, while if I was not able or interested to fancy a virtual travel through my building the project was probably mediocre. I had two problems towards the representation of the entity that was already born inside my brains: to represent it to myself and to communicate it to the others. It was obviously impossible to reach the second point without the first one. But though for my own understanding of the object of my imagination, the only necessary instruments were my head and eventually a few sketches, for making it clear to the others, I needed elaborated drawings made by hand or computer, a model, an essay maybe, and the hard work developed in order to achieve all those things often killed the pleasure of dreaming. This story is about the representation of something that doesn't physically exist (yet). The question is whether an architectural object which is not materially present (and not even drawn in a project) really does not exist. Couldn't it be that possibly my building does exist before (or better said in another dimension than) its materialisation, before its representation in a project designed on paper or on the computer screen and even before my attempt of mentally representing it to myself? The sculptures of Michelangelo existed enslaved in the marble rock until he set them free for being contemplated by everybody. Michelangelo did not consider himself to be an inventor which created products of his own imagination but was trying to reveal to the world hidden realities by his work. The "Myth of the Cavern" [7] contained in Plato's "Republic" pictures humanity like a crowd of recumbent people attached to the ground with the chains of their own ignorance and insensitiveness. In front of these people, there is a wall and behind them there is a parapet on which a fire burns near some things in movement. The fire drops the shadows of those things on the wall in front of the enchained crowd. Those shadows are the only knowledge the lying people get about the real world, which is actually behind them. In these conditions, an artist is nothing but a reproducer of the shadows which are projected on the wall, creating copies of the copies of the true things unless he breaks his chains, rises and 
turns his head. A difficult way starts: the blame of his neighbours who do not see what he sees, his impossibility to get down again and accustom with the dark again, etc. He can only afford his situation if he becomes aware of the light little by little and tries to convince his mates progressively of the truth that he discovered. This vision is continued in "The Banquet" [8] where Plato makes Socrates teach his mates the essence of love which he was himself taught by a wise woman, Diotima: love for a beautiful body and soul leads to love for all beautiful bodies and souls, gradually guiding to love for eternal beauty which has no body nor soul but is revealed through bodies and souls. Plato pointed out that the essence of the Universe is the world of ideas while the sensitive world we are living in is nothing but a copy of the ideal one given by our subjective ego. The artist does not know anything but receives the revelation of the real and transmits it to the others. Plotin [9] followed and continued the same reasoning while stating that knowledge is only possible to be obtained through the deep intuition of the ideal world given by communicating with the divinity in spiritual ecstasy. Plotin considered the human being able to realise the exposure of the idea and to make mankind contemplate it. A millennium and a half later Immanuel Kant [10] was defining beauty as: "pleasure without interest, finality without purpose and universality without concepts". Kant began to question about the subjectivity of aesthetic judgement, considering beauty to lie rather in the feelings of the subject than in the inner qualities of the object. Art itself is seen as being based on subjective rules, winning the right to the possession of absolute liberty while nature is obliged to obey to strong rules. This interpretation grew together with the period of exacerbation of senses in artistic representation and with the doubt that any knowledge of an absolute truth could ever be won besides scientific reasoning.

\subsection{Communicating architecture-2nd Story}

Some time ago we organized an opened discussion concerning the work of the Mexican architect Luis Barragán at the University. Each of our students was supposed to analyze one of the key concepts present in the architect's creation: colour, light, space, tradition, God, music, etc. The presentation referring to Barragán and music was made by somebody who was both a singer and an architect and who explained some musical notions (concerning duration, rhythm, composition, etc.) by finding their correspondents into the architectural details of Barragán's work, illustrated with images. Apparently Barragán himself stated "I think I could build with music". "I think I could sing on Barragán's architecture", replied our performer. This example is dealing with the strong relation between architecture and music, which is often intuited by both architects and musicians. The Pythagorean School dialled with the transcription of musical harmony using numbers and measures, which lead to wonderful relations between the material world, measured with the use of geometry, and music. The Universe itself is depicted to be based on "the harmony of the spheres". Following the line of this reasoning, other scientific approaches appeared later, such as the definition of the correspondence between the musical scale and the colours' spectrum, based on Newton's observations of "the law of harmonious proportions as the cosmological model of the reflection of the macrocosm in the microcosm" [11]. If a building can be interpreted as a musical work (a symphony, for example), its project is nothing else but the score of this symphony. Peter Zumthor also made this connection: "A plan, a project drawn on paper is not architecture but merely a more or less inadequate representation of architecture, comparable to sheet music" [12]. Let us observe the symphony is just an ideal concept, while our knowledge on it only comes through one of the various manners of interpretation an orchestra may employ. A concert heard in a music hall is the representation of the same work in the head of its composer. Beethoven never listened to the stage interpretation of some of his most famous works, being deaf. According to the Platonian perspective 
exposed above, it appears that representation is nothing but the (more or less skilful) copy of the Idea that exists beyond our everyday world.

\section{Separating the Virtual from the Real}

The intuition of reality requires the presence of the entire body and not only of one sense (the sight). The touch (one of the senses that have been deeply damaged by the visual era) can be primordially associated with the proof of the true existence of things. However, senses are only a demonstration of the existence of the real which is an a priori category that precedes experience not in a chronologic or psychological but in a logical way (this explanation of the term a priori is taken from the Kantian conception).

The term virtual is often associated with imagination and simulation. It is an a posteriori category, depending on the experience of the subject which is a necessary condition. Virtual is a creation of man, sometimes conscientiously and sometimes not. Entering the world of the virtual offers a perspective which is limited to the possibilities of representation offered by human nature (Fig. 1).

Representation is a virtual approach which may serve for the transmission of reality or may remain a goal in itself. In this case, it will be forever unsuccessfully fighting to surpass its limits. In architecture, this trick of the virtual can be avoided by integrating representation in the authentic experience of the act of building.

\section{An Itinerary through Architectural Representation}

\subsection{Byzantine Representation-The Effect of} Revelation

Byzantine art is a living example of artistic representation concerning an object that does not exist in the physical world (which does not mean it does not exist at all). The goal is the figuration of God and His empire, angels, saints, story, etc. It is an art which functions exclusively through revelation, without a direct imitation of the human world. It is the art of the heart in which the icon of God becomes God because the heart recognizes Him. His descent into the painted image (practically realising a $\theta \varepsilon o \varphi \alpha v i ́ \alpha$ ) is sure because the artist has called Him through prayer in intimate mystic communication (Fig. 2).

How was this conception applied to architecture? It seems that starting with a certain period (related with the eventful history of Byzantium - the iconoclastic era) constructions ceased to be based on previous drawings, though the Roman tradition was to employ
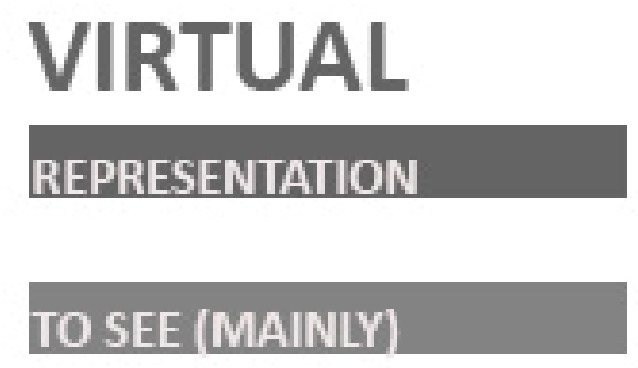

COMMON CODE OF RULES (FINITE)
DIVERSITY / INFINITY

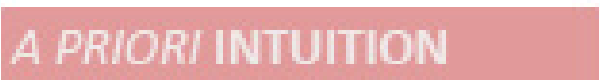

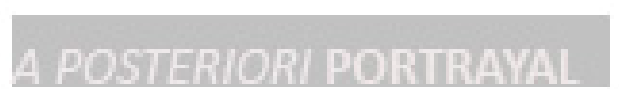

Fig. 1 The antithesis between "real" and "virtual" expressed in a scheme (by the author). 
plans, elevations and even perspectives. ${ }^{1}$ In the transitional period, the university-trained architect was replaced by the workshop-trained master builder. ${ }^{2}$ The interpretation of the act of building as unique action revealed by God in an unique site, by means of materials and techniques harmoniously used in relation with the place could also be a reason for the renunciation at previous drawings.

Byzantine architecture was based on the respect for the building substance that generated the effort of

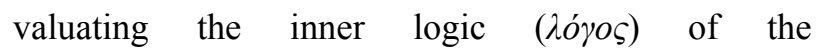
material - intimate relation of the builder with his work. The material plays for the Byzantine church the same role that the body plays for the soul in Christian religion - a cover that helps the inner evolution towards God [3]. The Byzantine temple has its own life, being an organism of unique appearance and this explains the fact that sketches and projects are getting as superfluous as mathematical equations in giving birth to a child. This also explains the acceptance of architectural imperfections that were generated by the material itself (it is almost impossible to find a 90

${ }^{1}(\ldots)$ did Byzantine masons use architectural drawings? None is mentioned in the vita of Nikon, and the phrase "in accord with God's plans" ( $\kappa \alpha \tau \dot{\alpha} \gamma \nu \omega \dot{\mu} \mu \varepsilon v \Theta \varepsilon \sigma v)$ sounds more to our purposes in the English translation; it actually refers to God's knowing/his judgement - rather than to his blueprint. It is known from Vitruvius that Roman architects utilized plans, elevations and perspectives and that this practice continued at least through the seventh century, when architects were still trained in the classical tradition. In the sixth century, Paul the Silentiary praised the architect Anthemios, who was "skilled to draw a circle and set out a plan". In the same period, Cassiodorus's formula for the palace architect also notes the significance of setting out ideas on paper. In such texts, such a plan is called skariphos ( $\sigma \kappa \alpha \rho i \varphi \circ)$ in contrast to the thesis ( $\Theta \dot{\varepsilon} \sigma l \varsigma)$, which was marked on the site (...). Although no proper drawings have been preserved from this period, an enigmatic sketch of the plan of an Early Christian basilica was found on a brick that had been reused at the medieval church of Saint Sofia in Ohrid [2].

${ }^{2}$ The architectural profession was transformed in the transitional period, with the theoretical orientation of the university-trained architect giving way to the practical orientation of the workshop-trained master builder. Did design practices continue unchanged? There are no clear references to Byzantine architectural drawings in the period after the Transitional period, and it would appear that, for most examples, drawings were not used [2]. degrees angle or a perfectly circled cupola in a Byzantine construction) (Fig. 3).

Another particularity of Byzantine architecture was the important role of the founder of a construction who was not the today "sponsor" or "client" but had complete responsibility for the sacred act of building and was often a saint if the construction was a church. ${ }^{3}$ The founder was important because he was the person who took the decision of the act of building, being directly inspired by God. That is why he had the highest responsibility in relation with the building site.

Byzantine standards of measure were taken from the human body directly: the foot ( $\pi 0 v \varsigma$ ) was divided into sixteen "fingers" ( $\left.\delta \alpha^{\prime} \chi \tau v \lambda o r\right)$. This is a direct consequence of the interpretation of the material building as a body, a shelter of an inner soul that is a part of the true divine world.

Byzantine architecture seems to be built "from above towards the bottom" which is a materialized expression of the act of building under the revelation of God. Every holy representation gets the properties of an icon - even a wall where the Citadel of Paradise or a town is painted. The purpose is not to copy the perception of the material surrounding world as obtained through the eye but to make the viewer figure (and feel) the true world with the help of the Holy Spirit. Orthodox image has the conviction to take the person who looks at it into the true world and not into the one revealed by our betraying senses, being an instrument and not a goal in itself. Orthodox representation is not virtual but pretends to be the key to the real world; it is not a result of imagination but a detailed transmission of reality revealed by the Holy Spirit, by means of a theological canon which assures the conditions for this communication. This explains

\footnotetext{
${ }^{3}$ The architectural profession was transformed in the transitional period, with the theoretical orientation of the university-trained architect giving way to the practical orientation of the workshop-trained master builder. Did design practices continue unchanged? There are no clear references to Byzantine architectural drawings in the period after the Transitional period, and it would appear that, for most examples, drawings were not used [2].
} 


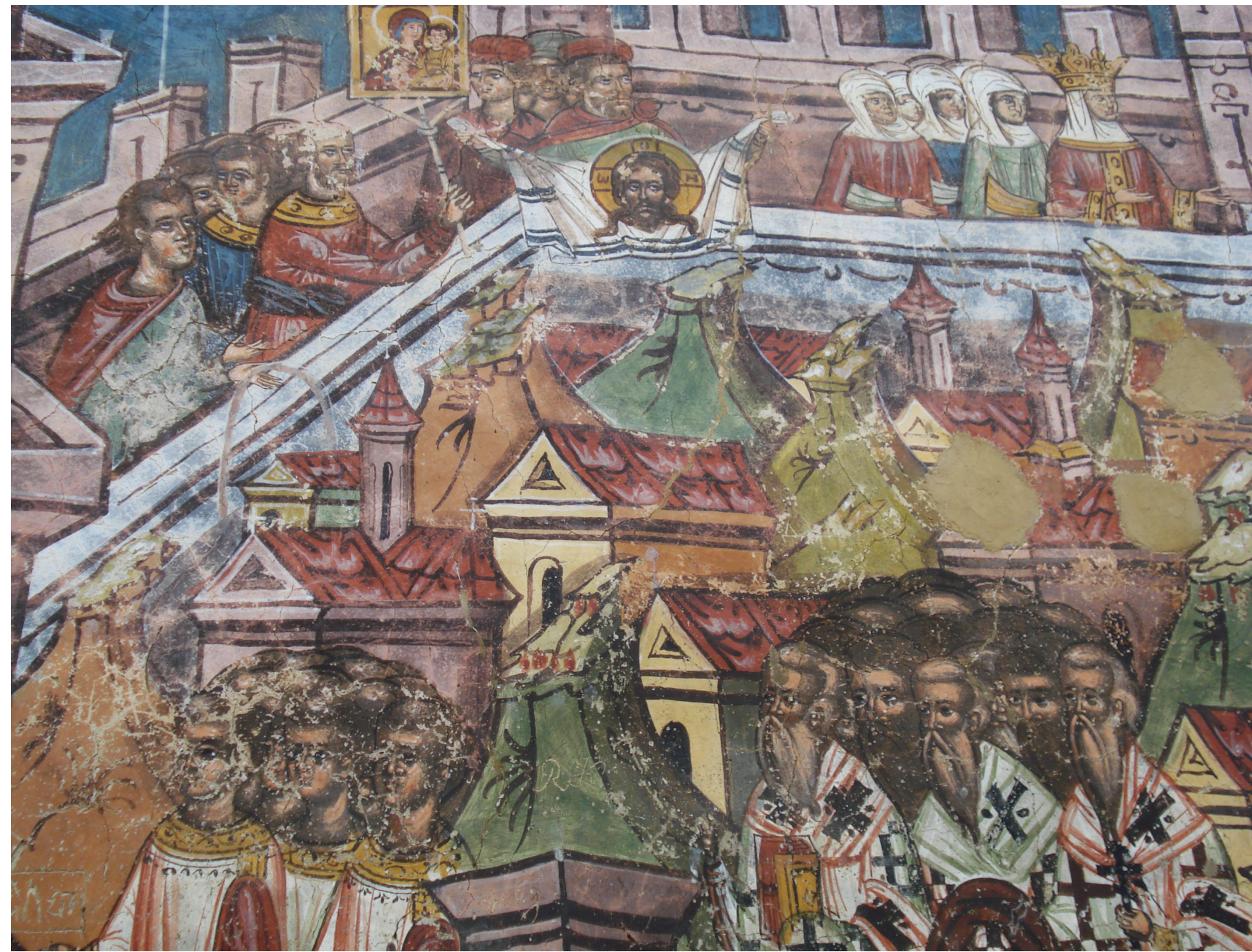

Fig. 2 Representation of the Conquest of Constantinople by the Turks - detail, the Monastery of Moldovița, Romania (photo by the author).

the refuse of innovation in the art and architecture of Byzantine tradition. Things are simple to understand whether we are situating in the perspective opened by the work of the famous historian of religions Mircea Eliade [13]. Eliade defines the two complementary dimensions of existence of mankind: within the sacred or the profane space. While the profane space is unlimited and quite amorphous, the sacred space is perfectly structured around a centre and an axis relating the earth to the sky. Differently from the geometrical space and corresponding to another kind of experience, the sacred space may define infinity of centres of the world which are perfectly available. There are two modalities of appearance of the sacred into the world: through the direct manifestation of
God $(\theta \varepsilon o \varphi \alpha v i \alpha)$ or through a gesture of mankind who invokes God by generating a sacred ritual (sacrifice of animals or even human sacrifice). The sacred is the real pre-eminently and its manifestation is the revelation of existence. "Creation implies a supra-abundance of real, an eruption of the sacred into the world", says Eliade [13]. The founding of a city, village or a house is a primordial approach, the repetition of the construction of the Universe itself.

As a conclusion, we can state that Byzantium is considering representation nothing but an instrument in defining reality - the genuine expression of the truth concentrated in God, which is for the Byzantine master a concrete presence and not just an idea. The truth is expressed in everything: from spatial 
composition to the revelation of the inner principles of construction material and to the harmonious enlacement of arts meeting in the ritual space: architecture, mosaics, painting, interior decoration, music (Gregorian singing and its specific acoustics), etc.

\subsection{Representation as Imagination. The Way to Virtual} Reality. Two Cases: Ancient Greek and Gothic Architecture

The history of artistic representation in harmony with the intuition of the supreme reality coincides with the history of humanity itself. I would like to stop on two outstanding cases: the one of ancient Greek and the one of Gothic architecture. Architecture of ancient Greece is drawing analogies with cosmic harmony, which suggests through its unchanged proportions the laws of the Universe and also the ethic possibilities of life. But the construction material has no life in itself, it gets a sense only by being submitted to the reason that formalizes it. The artist wants to please the intelligence of the viewer and that is why he is directly addressing to it.

Gothic has in common with Greek ancient architecture "the same submission of material to an a priori logical conception" [3]. The Gothic master forces the stone in order to get the final logical equilibrium of the building, which can be philosophically interpreted as the necessity for unity in the social submission to the given rules of God that the Church administrates for everybody.

Gothic is an example of synergy between the building site and architectural representation. The drawing does not impoverish the concrete work of its transcendental hard core of ideas and principles. Early Gothic master Villard de Honnecourt (beginning of the XIII-th century) [14] left us drawings that absolutely were not design plans but rather were an encyclopaedia to be used on the building site (Fig. 4). Although based on an inaccurate terminology, the work of Villard is the first attempt to create a system derived from building and drawing practice in the western world after antiquity. Representation for Gothic architecture was the transmission of a universal knowledge including scholastic reasoning and technical building prescriptions inseparably unified.

Both ancient Greek and Gothic architecture develop a living relation between the design and the construction of architecture, in perfect continuity-which also means a harmonic relation between faith and reason. ${ }^{4}$

\subsection{Senses in Representation. The Supremacy of the} Visual. The Death of Revelation.

The rediscovery of the concept of the ideal world as defined by Plato and the exaltation of form during Renaissance lead to a supra-evaluation of representation, gradually transforming it into a target in itself [15]. Architecture became impossible to be conceived in the absence of drawings and treatises. It

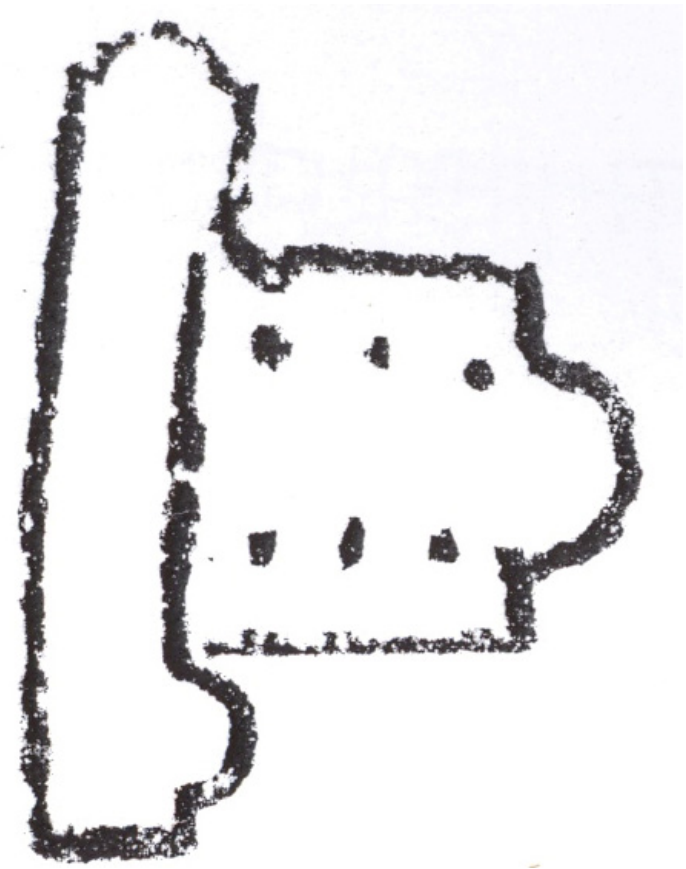

Fig. 3 Architectural drawing on an Early Christian brick, found in the narthex of Saint Sophia, Ohrid [2].

\footnotetext{
${ }^{4}$ Perhaps it is more important to think of design and the construction not as two separate exercises but as interrelated and simultaneous activities; as Coulton insists for Greek ancient architecture, planning continued through construction process [2].
} 


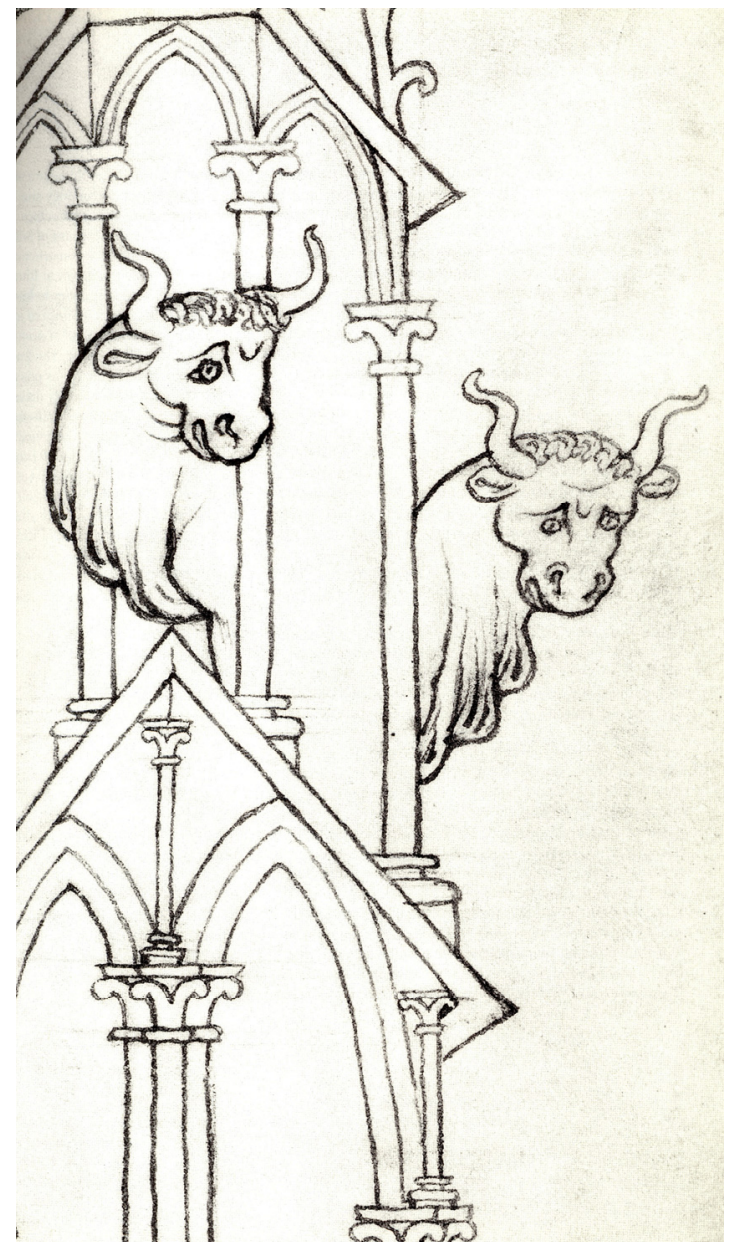

Fig. 4 Detail of the Tower of the Laon Cathedral, from Villard de Honnecourt-Codex (1230, Paris, Bibiothèque Nationale) [11].

is useless to insist on the importance that drawing had achieved in the period of Renaissance, on the perfection of perspective or the skilful parallels between the proportions of the human body and those of a building. Let us only observe that all these achievements where virtual, belonging to theory and were judged with only one sense: the sight. So strongly did Renaissance revolutionize our architectural perception that we can hardly imagine representation of spaces without using perspective.

Alberto Pérez-Gomez points out in the introduction of his work "Architecture and the Crisis of Modern Science" [6] that even if Alberti was already considering the distance between theory and practice, however Renaissance was still based on a strong metaphysical base. Practice represented the real poesis (creation), theory only having the role to guide and justify it. According to Pérez-Gomez, rupture between faith and reason only started in the 17th century with Galileo's speculations. With the development of science, the number lost its transcendental meaning, reducing itself to the role of an instrument used by man in order to achieve the technological control of the world. Scientific approach became the only available interpretation of a world that no more needed transcendental references. In this context, architecture was forced to remain enslaved to concepts as technology, efficiency, and economy.

One can follow how the role of image gradually transformed from the source for revealing a superior reality (the absolute truth) into an accurate representation of the external world as perceived by human senses (Renaissance) and later into an expression of subjective feelings (Baroque), or into a materialisation of reasonable technical principles (18th and 19th century). In the end, image divorces from any rules ${ }^{5}$ and proclaims its own reality (20th century) [16]. It is a revolution of the enchained spirit searching liberation from the straight canons of technology and efficiency after having lost the contact with the transcendental understanding of the world. ${ }^{6}$ But technology had already become too powerful and art itself started to depend on it. ${ }^{7}$

René Clair, the famous cineaste, enthusiastically exclaimed: Be my Lady and Master, oh, image! Erwin Panofsky pointed out that the cinema had brought

\footnotetext{
${ }^{5}$ The first artistic revolution of our century that proposed to proclaim the triumph of the image and its function of revelation and modification of an existential situation was the surrealistic revolution. Pointing out the poetic function, the creative function of the image intended in the same time to put into evidence its revolutionary character [16].

${ }^{6}$ André Breton also speaks about revolutions in 1925: "Only the image, in what it has of unpredictable and instantaneous, gives me the measure of possible liberation and this liberation is so complete that it scares me. Only using the force of images could revolutions be accomplished on time", cited by Uscătescu [16].

${ }^{7}$ While the first really revolutionary reproduction mean - photography (...) - erupted, art felt the proximity of the crisis and reacted with the theory of "l'art pour l'art", which means, with a theology of art [5].
} 
something that figurative art never had dreamed of: creating a dynamic space. This makes it turn into a transfiguration art which concentrates the supremacy in the aesthetic sensibility of our times [16].

This dynamic space created by the cinema entered our computers and our lives, decomposing the material world and guiding towards an absolute transitivity, which completely renounces the concept of place [17]. The receiver of artistic representation is a spectator endowed with absolute ubiquity. But the result of this general ubiquitous perspective is the disappearance of diversity. If everybody sees everything, how could one see something?

Here is an observation of Marcel Pagnol [17], on this topic: In a theatre, a thousand people cannot sit in the same place and so it can be said that none of them sees the same play (...) In order to address his public, the playwright needs to take a shotgun and load it with a thousand bullets in order to hit a thousand targets, while the cinema resolves this problem, given that wherever a spectator is sitting he sees exactly the image seen by the camera. If Charlie Chaplin looks at the lens, his image will look at the face of every viewer, whether they are on the right or on the left or upstairs or down.

The matter is whether this general common perspective has legitimacy in relation with reality defined as the dimension of true existence. Diversity, an infinity of different perspectives (the thousand bullets), is conscientiously exiled from the cinema, which is the declared acceptation of illusion, the offer of a parallel virtual world. Actually, the one thousand spectators have done nothing else than accepting a unique vision arbitrarily chosen by the holder of the camera, rather than embracing personal perspectives. They are obliged to agree with the image given by the camera because they lack the unmediated experience which could make them formulate a different opinion.

We can extrapolate this conclusion to architectural representation by referring to the elaborated computer animations of architectural objects that become more complicated to conceive than the building itself. Nowadays, every hidden corner of a house is possible to figure in detail before having any construction begun. But one can wonder if there is possibility to predict a transcendental meaning for this construction, a harmonious relation with the environing Universe. Can we design in absolute liberty (which could in fact mean absolute chaos), neglecting the place, which is the reference to the sacred space (as defined by Mircea Eliade)? Is it legitimate to invoke illusion as the final value of creation?

The sophisticated tools of today, leading to technically perfect results, are nothing else but the effect of the moral that accompanies some kind of technical use of the world [3]. This kind of moral leads to the tendency of replacing content by form. Representation has become a goal in itself, without a motivation of content behind it. Purpose as a generator of representation (for example, commercial purpose) is not replacing the concept of content which is not assimilated to a general motivation but is an inner reason of being. Representation is now swallowing a reality from which it has absolutely divorced by forcing to always anticipate it. For instance, I buy the image of the house of my dreams and cannot but hope that the real home that will come afterwards will be exactly like the image I have inverted in. The reign of the virtual gradually enslaved the real by mainly addressing to the sense which absorbs the most information: the sight. The body is not the only exiled from perception (through its other neglected senses) but the soul is also concerned. And let us underline that the soul alone is capable to receive the revelation of the real by transcendental communication.

\section{Conclusions: Bringing back the Body and Soul into Perception. The End of the Spectatorship Era}

We are not dealing with a new issue. Art was already aware of getting dominated by the visual in 
the beginning of the 20th century. Duchamp's fear of putting on canvas a painting that already existed in his head in order not to produce a poorer copy of it proved the belief in a transcendental system of values that the artist embraced. The anxiety of Proust to enter a world of essences, beside the ordinary existence, through a variety of experiences of his senses, is a part of the attempt to get a complete perception, in which body and soul are considered in equal parts. But maybe the clearest negation of the supremacy of the visual was made by the sculptor Constantin Brâncuşi. It is not the exterior form of things that is real but their essence stated the author of the sculpture for blind people [1]. The touch intervenes as an expression of primordial experience, as the symbol of authenticity.

Starting with the era of the cinema, we all are actually turning into spectators. Because it is difficult to be an actor in a world where nothing can be hidden and everybody's perspective is ubiquitous. But it is also tiring to watch an endless movie and it is hard to remain passive while you hear about tsunami and hurricanes killing thousands of people and you have got floods in your own city. We cannot continue to live by ignoring our nature as a whole and representation in architecture should try to serve the complete perception of living space with all our senses. The reconciliation of the rupture between the representation and the creation of an object is strongly needed.

What architectural education has to question about is whether its purpose is to prepare workers in the field of image, slaves of virtual representation or to form persons with the capacity of living and expressing the revelation of the truth. Such people could possibly be more useful to society by proposing viable solutions for sheltering the thousands of victims of unexpected calamities, by searching and learning to use alternative resources of energy, by adapting the houses they design to the new severe environment conditions, by putting a message into their architectural work.

The continuous refinement of representation without being aware of the essence that it has to serve is useless. The more perfect the telescope, the more stars there will be, maliciously observed Gustave Flaubert [17], proving that the search of absolute accuracy is a utopia if not dialling with a real content based on authentic experience. The precariousness of the means of expression may thus help, because when the tool becomes more complicated and extremely efficient, dexterity, ability and reasoning tend to reduce and to be replaced by automatic acts. We are living in the era of image, which is the symbol of illusion and virtual existence. Our life itself became no more than an interface between a neglected inner

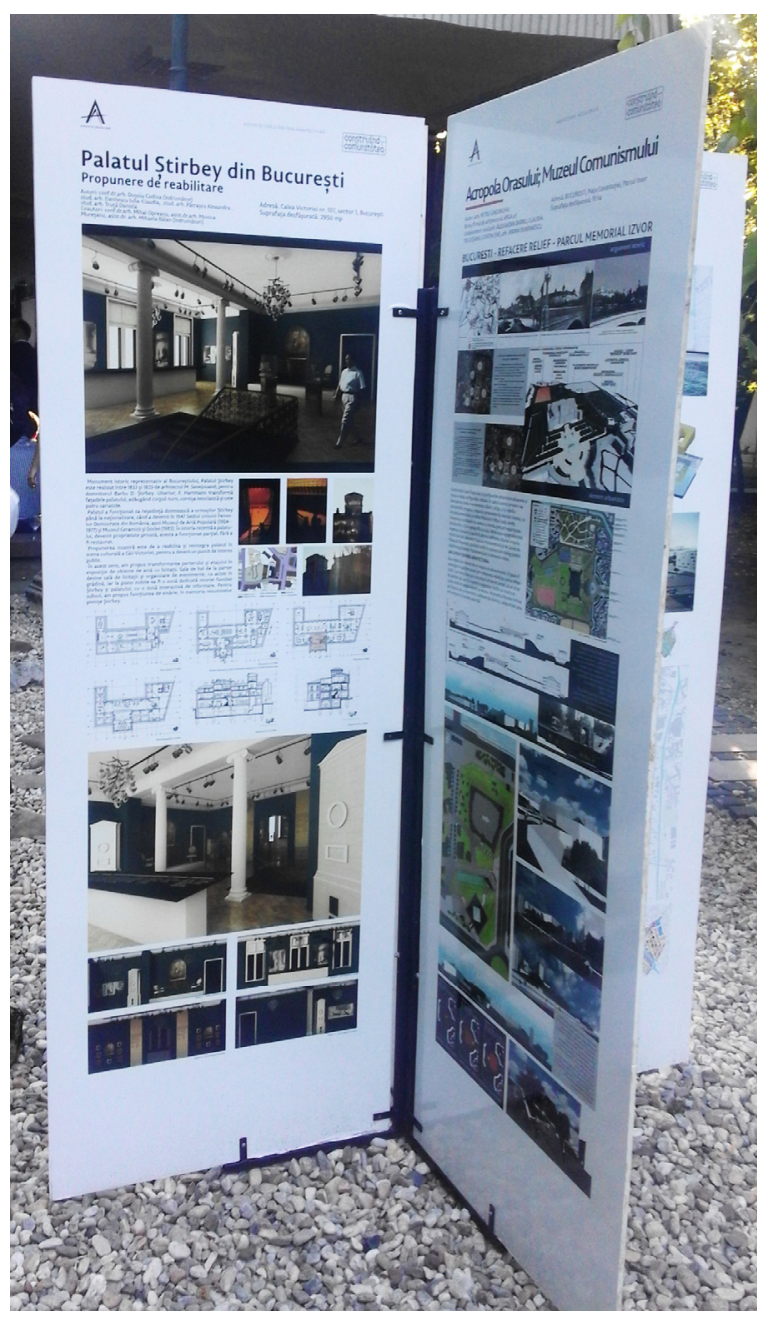

Fig. 5 The presentation of an architectural project in the Bucharest Annual Exhibition 2016 (photo by the author). 
personality and the indifferent chaotic world. When, how and how much can we renounce this "virtual life" which is more present everyday and everywhere? Creating through revelation and not by making mere copies, like the enchained artist from Plato's Myth of the Cavern could be a solution for reconsidering authenticity in our lives.

How can architecture effectively consider the search of this authentic experience and teach it? First of all, it can be found in the unmediated contact with the building site or the existing architectural object. You should believe only after having seen and measured...and touched with your hand!, Le Corbusier [18] said after having preferred to travel from Spain to Middle Orient for visiting the great monuments of the past instead of studying in order to obtain an academic diploma.

Architectural representation can decide between remaining in the domain of absolute simulation and proposing a strong interaction with the real world, in search of the essence of things (Fig. 5). Academic lectures and work with artisans, in the very place of the building site, within a concrete experience have historically been the two opposite ways of learning architecture. However, the topic of architectural representation appears in a different light when we locate the "real" beyond the material world that surrounds us. The experience of revelation can be embraced by everybody after its proper understanding. In any artistic field, imagination may grow together with revelation, leading to the true poesis.

To experience architecture in a concrete way means to touch, see, hear and smell it. Peter Zumthor observed [12]. Even if some of our senses, as well as our relationship with the transcendental world have been exiled from the perception of architecture, the defeat of human nature is not likely to be considered as a serious alternative. We might expect that it will finally claim its right to pursue the search of authentic personal experience.

\section{Acknowledgments}

The present paper is inspired by the conclusions of an essay created by the author [19] for the competition of essays on architectural education referring to architectural representation, EAAE Prize 2005-2007, organized in Copenhagen by the European Association for Architecture Education. The paper was selected among the 10 finalists but was never published. I considered useful to continue the ideas and statements presented in it, in order to make a step forward in analyzing the double quality of architectural representation: a virtual reality and an effect of transcendent revelation. I want to thank EAAE and the organizers of EAAE Prize 2005-2007 for giving me the possibility and interest to investigate the amazing world of architectural representation.

\section{References}

[1] Bellet, H. 1995. "Brancusi et son Temps." Beaux Arts Magazine (Hors série), 6-29.

[2] Ousterhout, R. 1999 Master Builders of Byzantium. New Jersey: Princeton University Press

[3] Yannaras, C. 2004. Liberty of the Moral ("Libertatea Moralei”). Bucharest: Anastasia Publishing House, Bucharest. (in Romanian)

[4] Procter, P. 1995. Cambridge International Dictionary of English. Cambridge: Cambridge University Press.

[5] Benjamin, W. 2015. The Work of Art in the Age of Mechanical Reproduction ("L'opera d'Arte Nell'epoca Della sua Riproductibilità Tecnica"). Torino: Einaudi. (in Italian)

[6] Pérez-Gomez, A. 1987. Architecture and the Crisis of Modern Science ("L'architecture et la Crise de la Science Modern"). Liège: Pierre Mardaga Editeur. (in French)

[7] Plato. 1996. The Myths ("Miturile lui Platon"). Bucharest: Anthology, Humanitas. (in Romanian)

[8] Plato. 1979. "The Banquet" in Complete Works ("Obras Completas "). Madrid: Aguilar. (in Romanian)

[9] Plotin. 1982. Eneadas. Madrid: Gredos.

[10] Kant, I. 1981. The Critique of Judgement ("Critica del Juicio"). Madrid: Espasa Calpe. (in Spanish)

[11] Briseux, C. E. 1752. "Traité du Beau Essential." Cited in Architectural Theory from the Renaissance to the Present. Köln: TASCHEN.

[12] Zumthor, P. 2007. A Way of Looking at Things from Thinking Architecture, Basel, Boston, Berlin: Birkhäuser. 
[13] Eliade, M. 1983. The History of Religious Ideas and Beliefs (Histoire des Croyances et des Idées Religieuses). Paris: Payot. (in French)

[14] Biermann, V., Borngässer, B., Evers, B., Freigang, Ch., Grönnert, A., Jobst, Ch., Kreimer, J., Lupfer, G., Paul, J., Ruhl, C, Sigel, P., Stewering, R., Thoenes, Ch., and Zimmer, J. 2003. Architectural Theory from the Renaissance to the Present. Köln: TASCHEN.

[15] Eliade, M. 1984. Contributions to the Philosophy of Renaissance (Contribuţii la Filosofia Renaşterii).
Bucharest: The Romanian Academy Publishing House. (in Romanian)

[16] Uscătescu, G. 1983. Introduction to the Ontology of Culture (Introducción a la Ontología de la Cultura). Madrid: Ediciones Forja, S.A. (in Spanish)

[17] Virilio, P. 1998. "Improbable Architecture." EL CROQUIS 91 (III): 4-15.

[18] Le Corbusier. 1971. The Essential Joys (Bucuriile Esențiale). Bucharest: Meridiane Publishing House.

[19] Duşoiu, E. C. 2007. Swallowing Reality. Representation in Architecture. Revelation-Tricking-Reasons. (unpublished) 